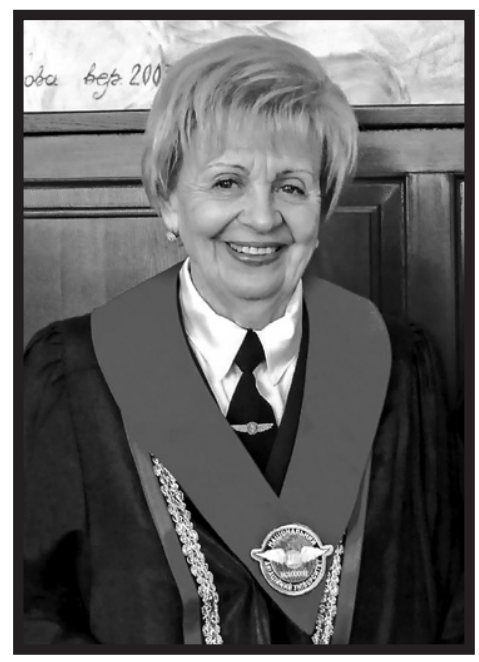

\title{
IN MEMORIAM: PROF. GALYNA ANDRIIVNA SUSLOVA (1930-2020)
}

On November 26, 2020, the Director of the ICAO Suslova Institute Prof. Galyna Andriivna Suslova went from us. She passed away for the proud 91, of which she has never spent a day without work. With her desire to work and live, she will always inspire us like no other.

Galyna Andriivna was born on February 27, 1930 in the Kursk region (Russia), in the family of an engineer and a teacher who lived and worked almost all their lives in Vilnius. Galyna Suslova has started her professional career quite rapidly. In 1953, she received a Diploma of Gorkiv University at the Faculty of English, and later became a teacher of English in Vilnius. Afterwards, she started working as a translator for Vilnius Airport, and in 1956 moved with her husband to Ukraine and started teaching at the Kyiv Institute of Civil Air Fleet. In 1965, Galyna Andriivna acquires another higher education by completing the team faculty of the Leningrad Academy of Civil Aviation and works as a leader.

With the proclamation of Independence, it was necessary to introduce standards of the International Civil Aviation Organization (ICAO) in Ukraine. So since 1992 Galyna Suslova has become one of the organizers of the ICAO seminar in Kiev, which used to be traditionally held in Moscow. In 2003, the ICAO Institute was established at the National Aviation University, which is due to the need to coordinate activities of a number of national centers and programs. Galyna Andriivna Suslova was the permanent director of the ICAO Institute.

Since 2003 Prof. Galyna Andriivna Suslova has been a Member of Editorial Board of the journal "Aviation". Even more, she was one of the initiators of the journal publishing.

Awarded with orders, medals and honorary titles of Ukraine, Bulgaria, Hungary, Lithuania and Russia. The cavalier of the Commander of the Cross of the Order of St. Stanislav. Honorary Professor of a number of international universities, including Vilnius Gediminas Technical University (Lithuania), Hankun Aviation University (South Korea). Honored member of the US Aviation and Cosmonautics Museum (Dayton), a Member of the World Women Association, who has made a significant contribution to the development of international civil aviation, author of over 180 scientific works.

Everyone who knew the Professor will always keep a bright and warm memory of her. God bless Galyna Andriivna Suslova.

Prepared by Prof. Gintautas Bureika, Editor-in-Chief of the research journal AVIATION 